\title{
Effect of Hydrocolloid (guar gum) Incorporation on the Quality Characteristics of Bread
}

Rodge AB ${ }^{1}$, Sonkamble SM${ }^{2}$, Salve $\mathrm{RV}^{2 *}$ and Syed Imran Hashmi ${ }^{3}$

${ }^{1}$ Dept of Food Chemistry and Nutrition, College of Food Technology, M.A.U, Parbhani (MS) India

${ }^{2}$ Dept of Food Science and Technology, MGM, College of Food Technology, Aurangabad (MS) India

${ }^{3}$ Dept of Food Trade and Business Management, College of Food Technology, M.A.U, Parbhani (MS) India

\begin{abstract}
Effect of guar gum on the rheological properties of dough, physico-chemical properties of bread, sensory characteristics of finished product and white bread quality was studied. At all levels of incorporation, there were increases water absorption from 61.2 to $64.5 \%$, lowered the dough development time from 6.20 to $5.60 \mathrm{~min}$, increased gluten development, increased dough stability, increased break down time from 37.3 to 40.5 min, higher the mixing tolerance index from 52.2 to $54.6 \mathrm{BTU}$ and increased the elasticity i.e. 72.3 to $74.6 \mathrm{BU}$ of the dough. The external characteristics like color of crust, symmetry, evenness, character of crust and aroma was improved linearly with increased the concentration of guar gum and also internal characteristics like color of crumb, taste and texture was improved.
\end{abstract}

Keywords: Hydrocolloids; Guar gum; Rheology; Sensory quality; Blended bread

\section{Introduction}

Hydrophilic colloids are those materials which give viscous solutions or form dispersions in water. In general, this criterion of water solubility to yield increased viscosity covers the large majority of gums used in the food industry [1]. Hydro colloidal materials have colloidal properties and are usually high molecular weight polymers. Chemically, most of them are polysaccharides and few are proteins such as gelatin and casein. In recent years, many synthetic hydrocolloid polymers have been developed. In actual practice the scientific term hydrocolloid has been used interchangeably with the shorter more common term gum. Nowadays, guar gum is standing as one of the cheapest Hydrocolloids in food processing with no harmful health hazard. The importance of hydrocolloids in food applications is due to their unique, functional properties, water binding capacity, reduction in evaporation rate, alteration in freezing rate, modification in ice crystal formation, regulation of rheological properties and participation in chemical transformations. The United State Food and Drug Administration regulate gums, classifying these compounds as either food additives or generally recognized as safe (GRAS) substances. Though, these are generally required at usage levels of less than 2 per cent to achieve desired properties in food systems [2].

Hydrocolloids have been widely used in food products to modify texture, improve moisture retention, control water mobility, and maintain overall product quality during storage. Wheat starch is basic ingredient in most foods. The gums improve granular structure and pasting behavior of starch during cooking and baking of food product where low gluten flour of soft wheat interacts with low gluten proteins [3]. They form molecular sols or gels \& exhibit colloidal characteristics in aqueous system. Gums and mucilage are generally categorized as hydrocolloids which have gain paramount importance in recent years because of their diverse and enormously increasing usage in food industries as thickening, foam and emulsion stabilizing, clarifying, binding, bulking, and suspending agents. Gums hydrocolloids are complex, viscogenic macromolecules which hydrate in cold or hot water to yield viscous or dispersion [4]. They have attributed the change in pasting viscosity of starch molecule especially when the starch dispersion heated in the presence of gums. The addition of thickening of gums would make the forces exerted on the granules in the shear field much larger than those encounter in starch-water suspension. These increased forces should significantly granular breakdown and the amount of material excluded in to the medium, if the gum was not completely dispersed when originally mixed with starch. Viscosity would be increased by improved solublization of the gum during heating.

Guar (Cyamopsis tetragonoloba L.) seed is a major source of gum having several industrial applications. The fraction remaining after extraction of gaur gum is a rich in protein (38-55\%) and is used in animal and poultry rations. Guar gum (also known Gum cyamopsis or guar flour) is mainly consisting of high molecular weight (approximately $50,000-8,000,000)$ polysaccharides (galactomannans) and is obtained from the endosperm of guar plant seeds. This plant has been cultivated in India and Pakistan for centuries. It can also be cultivated in southern hemisphere in semi-arid zones in Brazil, Australia and South Africa or in Southern part of the USA, like Texas or Arizona.

Guar gum is mainly consisting of high molecular weight polysaccharides composed of galactomannans which are consisting of a linear chain of $(1,4)$-linked $\beta$-D-mannopyranosyl units with $(1,6)$-linked $\alpha$-D-galactopyranosyl residues as side chains. The Galactomannans generally have the mannose to galactose in the ratio of 2:1. The clarified guar gum contains no longer cell structures and thus has higher galactomannan content. The guar gum is a white to yellowish white, nearly odorless, free-flowing powder with a bland taste

*Corresponding author: Salve RV, Dept of Food Science and Technology MGM, College of Food Technology, Aurangabad (MS) India, Tel: +919960738550; E-mail: rahul.salve03@gmail.com

Received September 21, 2011; Accepted November 19, 2011; Published December 05, 2011

Citation: Rodge AB, Sonkamble SM, Salve RV, Hashmi SI (2012) Effect of Hydrocolloid (guar gum) Incorporation on the Quality Characteristics of Bread. J Food Process Technol 3:136. doi:10.4172/2157-7110.1000136

Copyright: (c) 2012 Rodge AB, et al. This is an open-access article distributed under the terms of the Creative Commons Attribution License, which permits unrestricted use, distribution, and reproduction in any medium, provided the original author and source are credited. 
Citation: Rodge AB, Sonkamble SM, Salve RV, Hashmi SI (2012) Effect of Hydrocolloid (guar gum) Incorporation on the Quality Characteristics of Bread. J Food Process Technol 3:136. doi:10.4172/2157-7110.1000136

Page 2 of 7

and it is insoluble in organic solvents. The gum is soluble in cold water without heating to form a highly viscous solution. Guar gum solutions have buffering capacity and are stable at a wide range of $\mathrm{pH}$ 4.0-10.5.

Bread is a product with great nutritional value, consumed worldwide. In order to extend its shelf life, either different recipe formulations or specific storage conditions can apply. It is known that the bread staling is correlated with starch recrystallization at storage temperatures of $-1^{\circ} \mathrm{C}, 10^{\circ} \mathrm{C}$, and $21.1^{\circ} \mathrm{C}$ [5]. From caloric point of view bread is responsible for a great proportion of energetic daily intake. Having a caloric content ranging from $239 \mathrm{kcal} / 100$ grams (rye bread) to $282 \mathrm{kcal} / 100$ grams (white wheat bread), bread could provide up to $50 \%$ of daily recommended caloric intake. Some hydrocolloids were added to bread formula to improve the technological properties of dough and the final properties of breads. The addition of gums determines increasing of dietary fiber content and decreasing of caloric value by diluting the content especially through increasing water content [6]. These additions have shown to affect pasting properties, dough rheological behavior and bread staling. Gelatinization of cereal starch dispersions in the presence of different hydrocolloid strongly influences the viscosity of the hot starch paste. This behavior has been explained in terms of complex formation between starch polymers (amylose and amylopectin) and hydrocolloids during pasting.

There is an increasing interest for the application of food gums as additives in baking industry to confer various functionalities. The incorporation of hydrocolloids into flours mixture has the potential to improve texture characteristics besides serves as anti staling agent. Food gums could be widely used in baking industry to improve water holding capacity, to modify product's texture, volume, cell structure, and to maintain the product quality during storage [7].

The present investigation carried out with objectives like to standardize guar gum concentration in preparation of bread, to study effect of different levels of guar gum on physico-chemical properties of bread and to evaluate sensory characteristics of finished product.

\section{Material}

The present research was conducted at Department of Food Chemistry and Nutrition, Niche Area of Excellence laboratory of College of Food Technology, Marathwada Krishi Vidyapeeth, Parbhani during the year 2011-2012.

\section{Guar gum seeds}

Pure and healthy RGC-986 genotype variety guar seeds were collected from the farm of All India Co-Ordinate Research Project (AICRP) on Arid Legumes, M.K.V, Parbhani. They were cleaned and stored at room temperature.

\section{Other ingredients}

Maida was collected from Datta Krupa flour mill, MIDC, Parbhani while the other ingredients viz. sugar, salt, GMS, calcium propionate, compressed yeast (SAF Yeast, Mumbai) and Vanaspati (Dalda) was purchased from the Local Market of Parbhani.

\section{Chemicals and glassware}

Chemicals of analytical grade and sufficient glassware required are available in the P.G. laboratory, Department of Food Chemistry and Nutrition, College of Food Technology.

\section{Processing equipments}

The equipments were obtained from Department of Food chemistry and Nutrition, College of Food Technology, MAU, Parbhani.

\section{Methods}
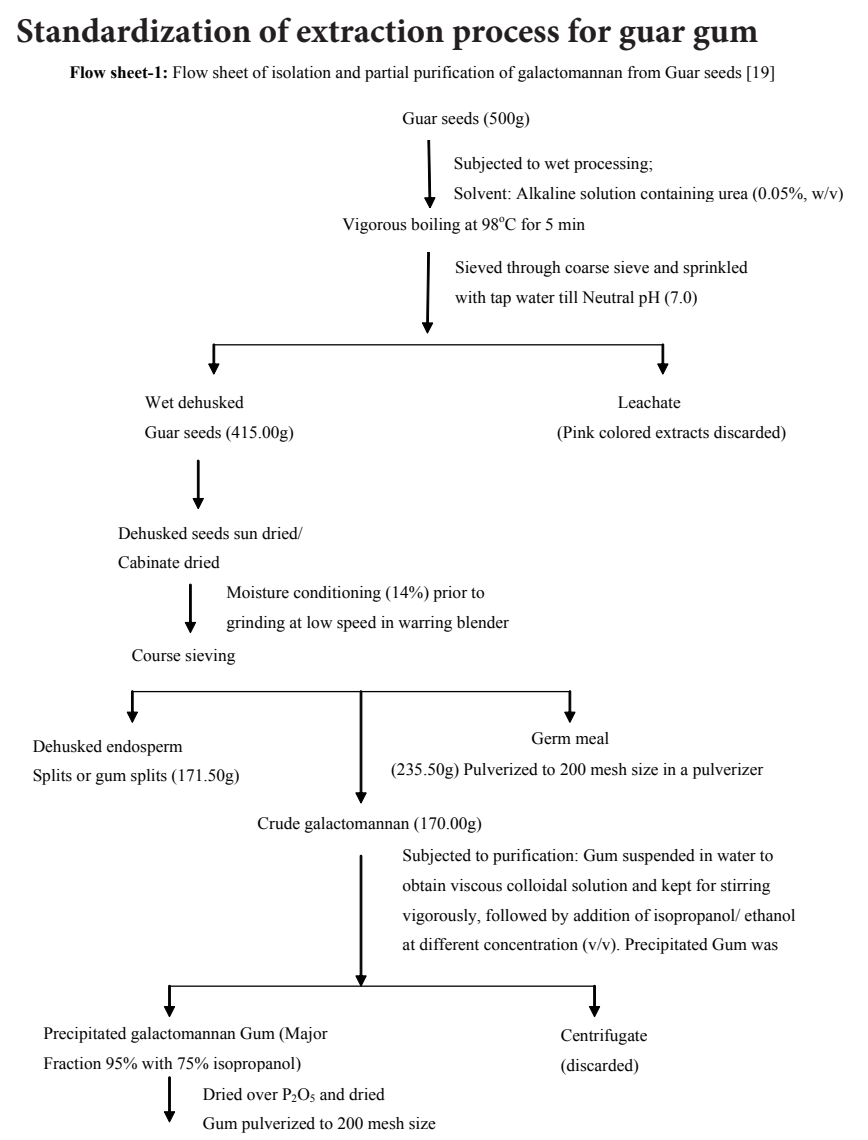

Partially Purified Galactomannan Gum (157.60g)

$$
\begin{aligned}
& \text { Further refining \& purification of the purified gum, subjected to } 60 \% \\
& \text { isopropanol extraction at } 70^{\circ} \mathrm{C} \text { for specific time (2hrs) \& filtered using } \\
& \text { filtration apparatus under vacuum and dried and pulverised to } 200 \text { mesh }
\end{aligned}
$$

Purified Galactomannan Gum

\section{Proximate analysis of flour}

Moisture Content, protein content, fat content, ash content, total carbohydrates was determined by AOAC [8].

Gluten content: $25 \mathrm{~g}$ of sample was weighed accurately in to a dish. Firm dough ball prepared with the addition of $15 \mathrm{ml}$ of water. The firm dough ball was kept under water in a beaker for 1 hrs .After one $\mathrm{hr}$ dough ball washed under tap water till no blue color formed after addition of iodine [8]. The whitish colored dough ball were dried in hot air oven (with the dish) for $2 \mathrm{hrs}$ at $130^{\circ} \mathrm{C}$, cooled in desiccator and weighed. The Gluten content calculated by using fallowing formula,

Gluten (on dry basis) $\%$ by mass $=10,000\left(\mathrm{M}_{2}-\mathrm{M}_{1}\right) /\left(100-\mathrm{M}_{3}\right) \mathrm{M}_{0}$ Where,

$\mathrm{M}_{2}=$ mass in gm (dish + dry gluten) $\mathrm{M}_{1}=$ mass in $\mathrm{gm}$ of empty dish

$M_{0}=$ mass in gm of flour taken for the test $M_{3}=$ percent of 
Citation: Rodge AB, Sonkamble SM, Salve RV, Hashmi SI (2012) Effect of Hydrocolloid (guar gum) Incorporation on the Quality Characteristics of Bread. J Food Process Technol 3:136. doi:10.4172/2157-7110.1000136

Page 3 of 7

moisture in sample.

Falling number: Falling number is measured as Hagberg Falling Number, measured in time (sec) taken by a plunger to fall through suspension of measured amount flour slurry which is heated at $100^{\circ} \mathrm{C}$ in water bath for $60 \mathrm{sec}$ [8].

Alcohol acidity test: It is an index of deterioration flour has undergone during storage. Alcohol acidity includes the enzymatic hydrolysis of fat and protein. Alcohol Acidity determined by using following formula,

\section{$\%$ Alcohol Acidity $=(24.52 \times$ Normality of $\mathrm{NaOH} \times \mathrm{A}) / \mathrm{M}$}

Where, $\mathrm{A}=$ Volume in $\mathrm{ml}$ of standard $\mathrm{NaOH}$ solution used in titration.

$\mathrm{M}=$ mass in gram of material taken for test.

Sedimentation value: Sedimentation test were used to assess the gluten quality and bread making potential. Sedimentation value measured in second as time taken by wheat flour to coheres and settles down in presence of Sodium Dodecyl Sulphate (SDS) [8].

Rheological characteristics: Rheological characteristics of flour samples were determined with brabender farinograph according to the method No.54-21 as described in AOCC [9]. Dough characteristics such as water absorption, dough stability, dough development time, tolerance index and softening of dough were interpreted from farinogram.

Water absorption: The water absorbed by the flour was the percent of water required to reach the center of curve on the 500 line.

Dough development time: The dough development time ( $\mathrm{min})$ was determined from farinogram as the time required for a curve to reach at its full development or maximum consistency showing the highest peak. High peak value is associated with strong wheat which has long mixing time.

Dough stability: This is the time ( $\mathrm{min})$ that top of the curve remains above the 500 B.U line and was measured from the arrival time to the departure time. Greater tolerance would indicate that the flour can stand for more mixing and the longest fermentation conditions.

Departure time/dough resistance: The time required for the curve to reach the point where the top of the curve left the 500 B.U line.

Tolerance index (TI): This indicates how fast a flour will breakdown after it has reached its full development. It was measured in Brabender Units. It was expressed as the difference between the center of the curve at the peak and center of the curve five min after the peak.

\begin{tabular}{|c|c|c|}
\hline Sr. no. & Ingredients & Weight $\mathbf{( g )}$ \\
\hline 1 & Flour & 100.0 \\
\hline 2 & Water & 60.0 \\
\hline 3 & Sugar & 2.0 \\
\hline 4 & Shortening & 2.0 \\
\hline 5 & Salt & 1.5 \\
\hline 6 & Yeast & 1.0 \\
\hline 7 & SMP & 1.0 \\
\hline 8 & GMS & 0.3 \\
\hline 9 & Calcium propionate & 0.2 \\
\hline
\end{tabular}

Table 1: Bread recipe used in bread production.

\begin{tabular}{|c|c|}
\hline Sample & Guar gum (g/100g flour) \\
\hline A & 0.25 \\
\hline B & 0.50 \\
\hline C & 0.75 \\
\hline D & 1.0 \\
\hline E & 0.0 \\
\hline
\end{tabular}

Table 2: Different dose of Guar gum used in bread production.

Softening of the dough: Degree of softening was measured at the difference between the center of the curve at peak and centre of the curve at 12 min after the peak. It was expressed in Brabender Units (BU).

Formulation, preparation of bread: The bread was prepared in the Bakery Plant of the College of Food Technology, Marathwada Krishi Vidyapeeth, Parbhani, using straight dough method [9]. The recipe was used for preparation of bread mentioned below in Table 1 and guar gum was used in recipe in different concentration as mentioned in Table 2 .

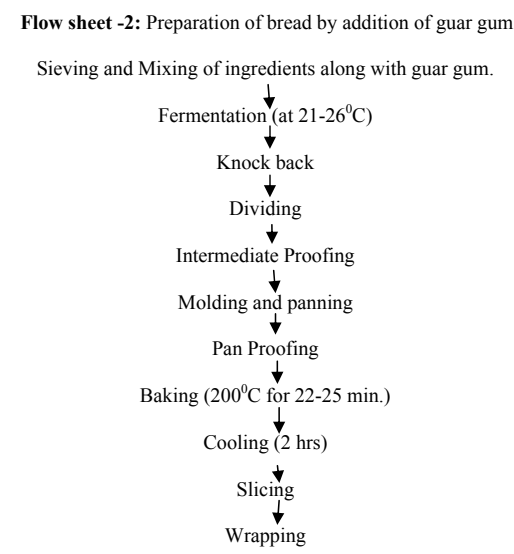

\section{Result and Discussion}

The results were discussed in the view of relevant scientific literature available in the country and elsewhere. The obtained results are presented in the following headings.

\section{Chemical analysis of guar gum}

The chemical composition of guar gum is presented in Table 3. It was observed from table that purified guar gum contained total carbohydrate 87.72 per cent, protein 0.86 per cent, lipid 0.15 per cent, moisture 9.70 per cent and Ash 0.64 per cent. It is evident from results that guar seed may be successfully exploited as a potential source of galactomannan gum. The results are more or less similar as reported by Rodge et al. [10].

\section{Proximate composition of wheat flour}

During present investigation, efforts were made to study the chemical composition of wheat flour. Different chemical compositional parameters viz. proximate composition, mineral content and vitamin content of wheat flour were determined and presented under following suitable heading (Table 4).

It could be observed that obtained wheat flour found to contain 12.5 per cent of moisture. The lower moisture content of wheat flour justifies the suitability for long term storage without deterioration. The carbohydrate content of wheat flour was found to be 69.86 per cent 
with the protein content of 12.8 per cent. Higher protein content is important for strong elastic dough which having high water absorptive capacity, excellent gas holding properties and will yield bread with good volume ,grain and texture. The observed values for crude fat and ash content were 1.30 and 0.8 per cent respectively, with the theoretical energy value of $326 \mathrm{Kcal}$.

\section{Chemical characteristics of wheat flour}

It could be observed from the above Table 5 that gluten content of wheat flour (Maida) was 11.35 per cent. This clearly indicated that wheat flour used was strong in nature. The flour contains optimum alcoholic acidity was $0.12 \%$ because flour which stored for long time gives higher values of alcoholic acidity and hence it is index of deterioration that higher the alcoholic acidity lowered the quality of the wheat flour. Sedimentation value of flour represents quality of gluten and one of the instant ways to determine the performance of flour in bread manufacturing. The obtained results for sedimentation value of wheat flour were $27.6 \mathrm{ml}$ which represent good quality of flour. The Falling number of flour represents the viscous behavior of flour due to present of $\alpha$-amylase. The obtained values of $310 \mathrm{sec}$ for falling number represent the freshness of flour.

\section{Rheological characteristics of dough prepared with different incorporation level of guar gum}

Rheological characteristics reflect the dough properties during processing and the quality of final product. These rheological properties of dough are water absorption, dough development time, dough stability, time to break down ,mixing tolerance index and elasticity on dough prepared with different incorporation level of guar gum studied and tabulated in the below Table 6 .

\begin{tabular}{|c|c|c|}
\hline Sr. No. & Chemical constituents & Guar gum \\
\hline 1. & Moisture (\%) & 9.70 \\
\hline 2. & Crude protein (\%) & 0.86 \\
\hline 3. & Crude lipid (\%) & 0.15 \\
\hline 4. & Total Ash (\%) & 0.64 \\
\hline 5. & Total carbohydrate (\%) & 87.72 \\
\hline
\end{tabular}

${ }^{*}$ Each value represents average of three determinations

Table 3: Chemical composition of guar seed gum.

\begin{tabular}{|c|c|c|}
\hline Sr no. & Content & Per cent (\%) \\
\hline 1 & Moisture (\%) & 12.5 \\
\hline 2 & Ash (\%) & 0.8 \\
\hline 3 & Crude fat (\%) & 1.30 \\
\hline 4 & Crude protein (\%) & 12.8 \\
\hline 5 & Crude fibre (\%) & 0.6 \\
\hline 6 & Total Carbohydrate (\%) & 69.86 \\
\hline 7 & Energy (Kcal) & 326 \\
\hline
\end{tabular}

* Each value represents average of three determinations

Table4: Chemical Composition of Wheat flour.

\begin{tabular}{|c|c|c|}
\hline Sr. No. & Chemical properties & Result \\
\hline $\mathbf{1}$ & Gluten content(\%, wet basis) & 11.35 \\
\hline $\mathbf{2}$ & Alcohol acidity $(\%)$ & 0.12 \\
\hline $\mathbf{3}$ & Sedimentation value $(\mathrm{ml})$ & 27.6 \\
\hline $\mathbf{5}$ & Falling number $(\mathrm{Sec})$ & 310 \\
\hline
\end{tabular}

* Each value represents average of three determinations

Table5: Chemical characteristics of wheat flour (Maida).
It was observed that dough containing highest amount of water absorption was sample D while control sample (E) showed to posses lowest water absorption capacity. The water absorption of sample A containing 0.25 per cent of guar gum was 61.2 per cent which increased with increase in concentration of guar gum and reached up to 64.5 per cent in sample having 1 per cent of guar gum. The increase in water absorption capacity of dough may be due to ability of guar gum to absorb water in their interrelated network and interaction with starch granules. Higher water absorption capacity of dough represents consistency which is desirable in bread making. Therefore, it is found that increase in concentration of guar gum linearly increases water absorption capacity of dough. These results were expected due structural modification in dough due to incorporation of guar gum which allows more water absorption due to hydrogen bonding [11].

With respect to dough development time, it could observed from the Table 6 that dough development time found to correlated inversely with the concentration of guar guar and higher dough development time i.e. $6.20 \mathrm{~min}$. while the sample containing 1 per cent of guar gum found to have lowest dough development time $(5.60 \mathrm{~min})$. The different between the control sample and dough with higher level of guar gum is merely of $0.6 \mathrm{~min}$, however it could significantly impart in reducing the time of processing in industries following batch process of mixing.

Stability of dough is the function of gluten development. The results revealed that increase in concentration of guar gum enhanced the gluten development and hence the stability of dough increased with the increase in concentration. These results indicated that dough which contains high guar gum concentration exhibited higher tolerance index to over mixing. This advantage is preferred on industrial scale [12].

Mixing tolerance index parameter represents resistivity of wheat flour to the mixing, higher the mixing tolerance index values then stronger the flour. The mixing tolerance index of the Sample D indicated maximum value of 54.6 BU. while Sample E showed minimum tolerance index of $50.1 \mathrm{BU}$. Elasticity improved as there was increased concentration of guar gum. The addition of guar gum can induce dough strengthening, which was likely because of a strong interaction between galactomannan and flour proteins [13]. From the parameters obtained, the maximum score for elasticity was obtained by sample D was 74.6 B.U. While minimum score was found to be for sample E was 71.6B.U.

\section{Effect of different level of guar gum on sensorial qualities of bread}

During present investigation, efforts were made to study the effect of different levels of guar gum on external as well as internal quality characteristics of breads on 9 point Hedonic scale and the results are discussed under following suitable headings.

\section{Effect of different incorporation level of guar gum on external sensorial characteristics}

External quality characteristics of bread play a pivotal role to attract consumers to purchase. Generally, breads are packed in transparent polyethylene bags, so that the consumer can judge the quality of bread on the basis of its external quality parameters such as volume, color, symmetry, crust characteristics, etc. To observe the effect of different levels of guar gum incorporation on external characteristics, the semitrained panelist members who were having prior experience of judging the sensorial quality of bakery products were asked to evaluate the 
Citation: Rodge AB, Sonkamble SM, Salve RV, Hashmi SI (2012) Effect of Hydrocolloid (guar gum) Incorporation on the Quality Characteristics of Bread. J Food Process Technol 3:136. doi:10.4172/2157-7110.1000136

Page 5 of 7

external characteristics on 9 point Hedonic scale with 1 to 9 where higher values represent higher consumer acceptability. The obtained results for external sensorial characteristics of bread are summarized in Figure 1.

Amongst varies studied external characteristics of bread, volume and color and aroma of bread were considered most important by the panelist members. The volume of bread found to increase linearly with increase in concentration of guar gum and maximum volume was observed in sample D containing 1 per cent of guar gum. The increase in volume of treated samples may be attributed to higher water absorption capacity of guar gum; during baking this moisture get evaporated and hence increase in vapor pressure results in improvement of loaf volume of bread.

The color of bread crust is a function reducing sugars as these reducing sugars during baking caramelized to produce dark brown color of bread [14]. Hence, the color of treated sample remained more or less similar to that of control sample. Symmetry and evenness of bread remained as a function of gluten strength and uniform vapor production during baking. It could be observed form the table that incorporation of guar gum increased the uniform vapor product and hence the symmetry and evenness of bread form linearly with increase in concentration of guar gum.

The character of crust represents the hardness of bread crust. Higher curst hardness represents superior quality as it can sustain minor impact or attrition during transportation and handling. Incorporation of guar gum does not have significant impact on the character crust of bread. Aroma of bread is also observed to remain more or less similar to control sample irrespective to concentration of guar gum incorporation.

It was found that the overall acceptability in terms of external characteristics of bread improved linearly with increase in concentration of guar gum and maximum score was secured for sample D containing 1 per cent of gaur gum.

\section{Effect of different levels of guar gum on internal characteristics of bread}

During present investigation, various internal parameters were studied and the results are summarized in Figure 2. The effect of guar gum incorporation on internal characteristics of bread revealed that guar gum incorporations have significant effect on internal characteristics of

\begin{tabular}{|c|c|c|c|c|c|c|c|}
\hline \multirow{2}{*}{$\begin{array}{l}\text { Sr. } \\
\text { No. }\end{array}$} & \multirow[t]{2}{*}{ Sample } & $\begin{array}{c}\text { Water absorption } \\
(\%)\end{array}$ & \multirow{2}{*}{$\begin{array}{c}\text { Dough development } \\
\text { time } \\
\text { (min) }\end{array}$} & \multirow[t]{2}{*}{\begin{tabular}{|c|} 
Dough stability \\
(min)
\end{tabular}} & \multirow[t]{2}{*}{$\begin{array}{l}\text { Time to break down } \\
\text { (min) }\end{array}$} & \multirow[t]{2}{*}{ Mixing tolerance Index (BtU) } & \multirow[t]{2}{*}{ Elasticity (BU) } \\
\hline & & & & & & & \\
\hline 1 & A & 61.2 & 5.95 & 5.11 & 37.3 & 52.2 & 72.3 \\
\hline 2 & $\mathrm{~B}$ & 62.7 & 5.83 & 5.15 & 39.7 & 53.4 & 72.5 \\
\hline 3 & C & 63.2 & 5.70 & 5.18 & 38.4 & 53.5 & 73.8 \\
\hline 4 & $\mathrm{D}$ & 64.5 & 5.60 & 5.20 & 40.5 & 54.6 & 74.6 \\
\hline \multirow[t]{3}{*}{5} & $E$ & 59.8 & 6.20 & 5.09 & 37.2 & 50.1 & 71.6 \\
\hline & $\mathrm{SE} \pm$ & 0.816 & 0.104 & 0.020 & 0.654 & 0.492 & 0.529 \\
\hline & CD at $5 \%$ & 2.450 & 0.313 & 0.0621 & 1.962 & 1.478 & 1.587 \\
\hline
\end{tabular}

* Each value represents average of three determinations

Table 6: Rheological characteristics of dough prepared with different incorporation level of guar gum.

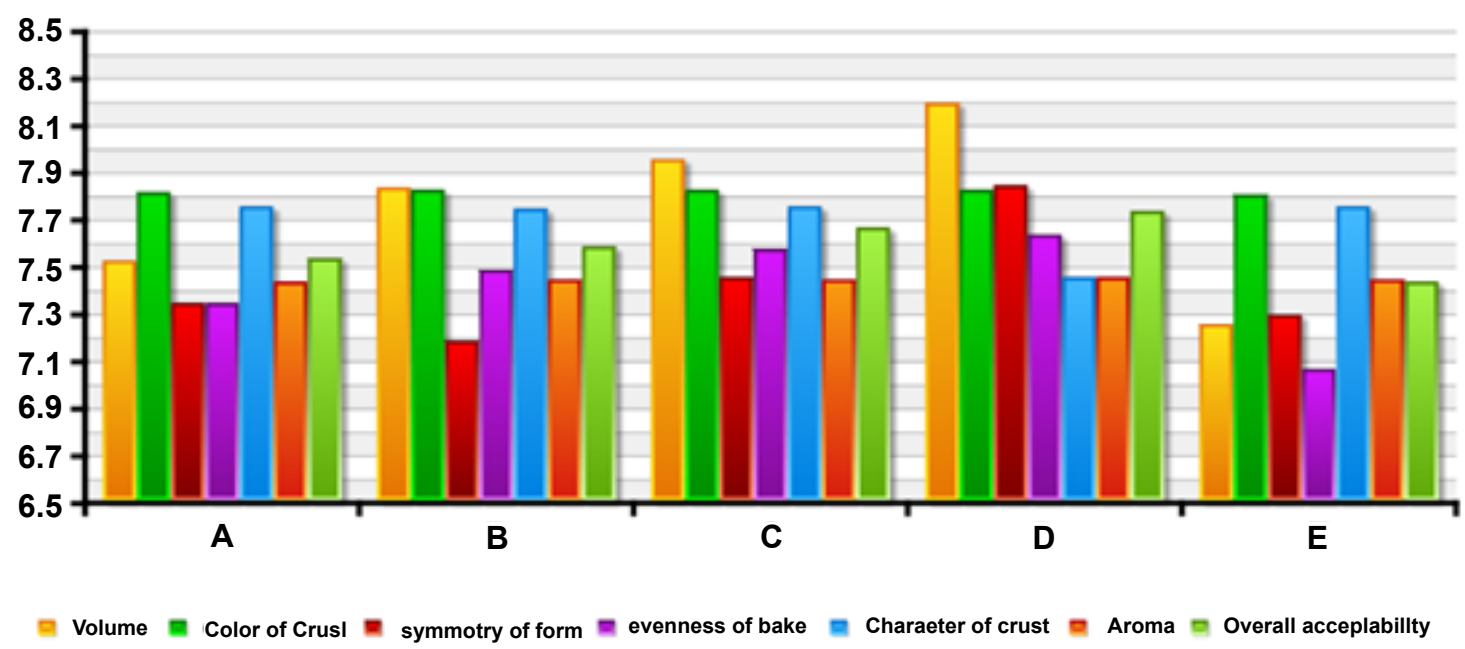

Figure 1: Effect of different levels of guar gum on External sensorial characteristics of Bread. 
Citation: Rodge AB, Sonkamble SM, Salve RV, Hashmi SI (2012) Effect of Hydrocolloid (guar gum) Incorporation on the Quality Characteristics of Bread. J Food Process Technol 3:136. doi:10.4172/2157-7110.1000136

Page 6 of 7

bread. Guar gum incorporation results in enhancement of grain and maximum grain score were obtained at higher gum concentration. Due to addition of guar gum at different levels the a fine silky grain was obtained in which cells are small, uniform, elongated, rather than round, thick, and large. Sample D found to be highest value for grain of loaf and control sample E got minimum score.

\section{Physical properties of bread with different levels of guar gum}

In order to understand the significance the effect of guar gum incorporation level on the physical properties, different parameters like loaf volume, specific volume, crust color, crust to crumb ratio and crumb firmness were investigated and presented in this Table 7 [15].

Loaf Volume (ml): The volume of bread loaf was measured by rapeseed displacement technique. The mean values of loaf volume illustrated the effect of guar gum treatment on the volume of the bread loaves. It was found that guar gum addition caused increase in bread volume linearly and maximum volume was observed in case of sample $\mathrm{D}(820 \mathrm{ml})$ and minimum value for this parameter was recorded in control sample. This effect may be due to higher gluten development and water retention capacity of dough which improved due to guar gum incorporation.

Specific Volume $\left(\mathrm{cm}^{3} / \mathbf{g m}\right)$ : Similarly, the specific volume of the bread samples was calculated and the best treatment in this regard was found to be in sample D $3.25 \mathrm{~cm}^{3} / \mathrm{g}$; Whereas, control sample was at bottom with specific volume $2.25 \mathrm{~cm}^{3} / \mathrm{g}$. The results pertaining to the specific volume of bread indicated that treatment resulted in breads with less density and high volume and hence, preferred by the consumers.

Crust color: The results obtained for crust of color showed highest value was 6.2 for sample D and lowest value for control sample. Crust color is an important parameter concerning the consumer acceptability towards bread. It is revealed from the means that the treatments showed significant variations in the color of crust. The color of crust depends upon extent of caremelization of sugar present in the bread sample.

Crust to crumb ratio: It could be observed from the Table 8 that obtained crust to crumb ratio found to be in the range of 0.245 to 0.280 . The highest value obtained for crust to crumb ratio by sample $\mathrm{D}$ while sample E showed lowest value. The values obtained for crust to crumb ratio indicated that there was no much difference found in these values as no effect of different incorporation level of guar gum on the crust to crumb ratio.

Crumb firmness ( $\mathrm{g}$ force): The addition of guar gum increased loaf volume and bread score and reduced crumb firmness. The optimum levels for crumb firmness were obtained at higher levels of guar gum addition. The guar gum optimum level reduced sheeting work

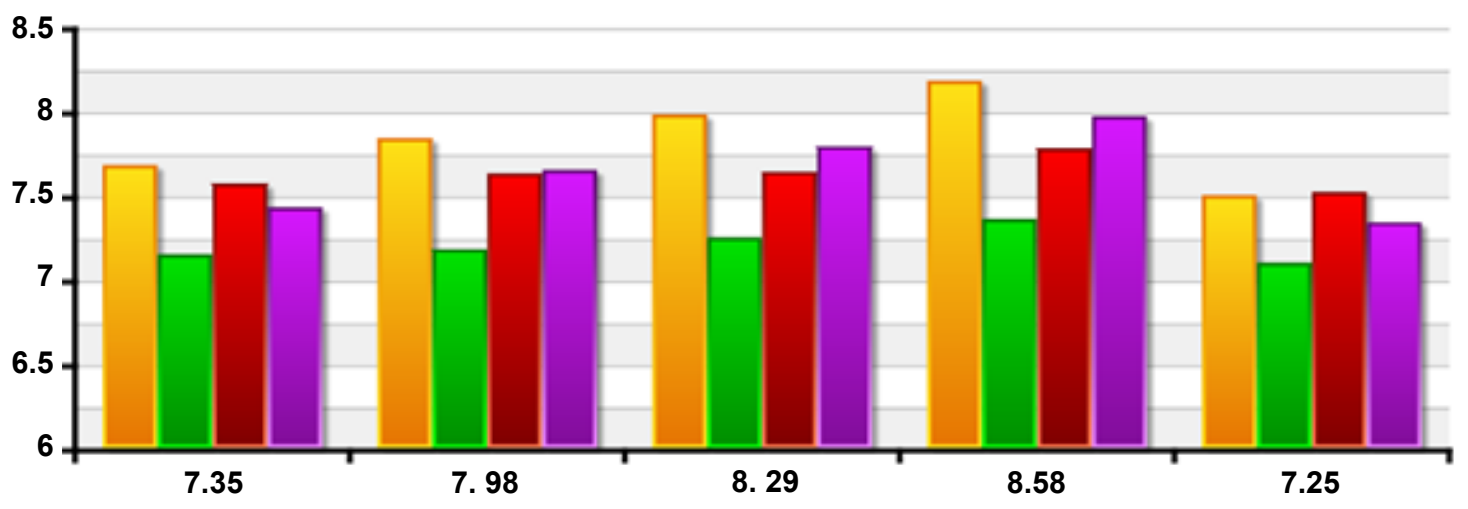

Color of crumb

Taste

Texture

Overall acceptability

Figure 2: Effect of different incorporation level of Guar Gum on Internal characteristics.

\begin{tabular}{|c|c|c|c|c|c|}
\hline Sample & $\begin{array}{l}\text { Loaf } \\
\text { Volume } \\
\text { (ml) }\end{array}$ & $\begin{array}{l}\text { Specific Volume } \\
\left(\mathrm{cm}^{3} / \mathrm{gm}\right)\end{array}$ & Crust color & Crust to crumb ratio & $\begin{array}{c}\text { Crumb firmness } \\
\text { (g force) }\end{array}$ \\
\hline A & 728 & 3.06 & 4.5 & 0.255 & 1.11 \\
\hline B & 785 & 3.15 & 5.0 & 0.265 & 1.86 \\
\hline C & 790 & 3.21 & 5.8 & 0.274 & 2.57 \\
\hline D & 820 & 3.26 & 6.2 & 0.280 & 2.86 \\
\hline$E$ & 635 & 2.25 & 5.5 & 0.245 & 1.65 \\
\hline $\mathrm{SE} \pm$ & 32.81 & 0.186 & 0.2991 & 0.0063 & 0.3074 \\
\hline CD at $5 \%$ level & 98.43 & 0.558 & 0.8973 & 0.0189 & 0.9222 \\
\hline
\end{tabular}

* Each value represents average of three determinations

Table 7: Physical properties of bread prepared with different incorporation level of guar gum. 
Citation: Rodge AB, Sonkamble SM, Salve RV, Hashmi SI (2012) Effect of Hydrocolloid (guar gum) Incorporation on the Quality Characteristics of Bread. J Food Process Technol 3:136. doi:10.4172/2157-7110.1000136

Page 7 of 7

\begin{tabular}{|c|c|c|c|c|c|c|c|}
\hline Sample & Moisture (\%) & Protein (\%) & Fat (\%) & Carbohydrate(\%) & Crude Fiber(\%) & Ash (\%) & Energy (Kcal) \\
\hline A & 36.2 & 11.71 & 2.42 & 61.29 & 2.41 & 1.47 & 313.78 \\
\hline B & 36.9 & 11.58 & 2.39 & 61.72 & 2.38 & 1.45 & 314.71 \\
\hline C & 38.8 & 11.23 & 2.32 & 59.80 & 2.31 & 1.42 & 305.00 \\
\hline D & 40.5 & 10.91 & 2.26 & 57.74 & 2.24 & 1.26 & 294.94 \\
\hline$E$ & 35.5 & 11.85 & 2.45 & 61.5 & 2.45 & 1.50 & 315.45 \\
\hline S.E \pm & 0.5281 & 0.0107 & 0.0086 & 0.2174 & 0.2588 & 0.0093 & 1.6895 \\
\hline CD & 1.5843 & 0.0321 & 0.0258 & 0.6522 & 0.7764 & 0.0279 & 5.0685 \\
\hline
\end{tabular}

*Each value is average of three determinations

Table 8: Chemical composition of bread prepared with different incorporation level of guar gum.

requirements, resulting in softer dough. The crumb firmness is the force required to compress slice of bread $25 \mathrm{~mm}$ thick by 25 per cent. The value obtained indicated the softness of bread.

\section{Chemical composition of bread prepared with different incorporation level of guar gum}

In order to state the significance of incorporation of different level of guar gum on nutritional quality characteristics bread, it is necessary to observe the effects on chemical composition like moisture, protein, fat, carbohydrate, crude fiber, ash of bread sample.

The nutritive value of bread remained more or less similar to that of controlled sample. The significant variations were observed in moisture content of bread and bread containing 1 per cent of guar gum showed to retain 40.5 per cent of moisture after baking. Total carbohydrate content of bread may be improved, maximum up to 1 per cent due to incorporation guar gum; however the lower obtained value were due to wet basis analysis of chemical constituents of bread. Thus guar gum incorporation in bread showed very slight variations in nutritional composition bread.

\section{Conclusion}

In the baking industry hydrocolloids are of increasing importance as bread making improvers [12]. Usually, the addition of hydrocolloids to dough improves its stability and quality criteria such as increased water absorption, specific loaf volume and the viscoelastic properties [16]. From this study concluded that all from examined hydrocolloids positively affected dough stability and proved higher water absorption capacity. These compounds also affected sensory properties of final products in different ways. For instance when looking for the reduction of the staling, guar gum is the best additive due to both its softening and retarding the firming of the baked goods crumb effects. As a consequence of the great variation in the effect promoted by the different hydrocolloids, a systematic study is necessary about the influence of a range of hydrocolloids in the quality of wheat bread [17].

\section{References}

1. Glicksman (1965) Importance of hydrophilic gum constituents in processed foods. J Food Tech 23: 942-947.

2. Anonymous (2001) Market needs-tomato products. Prepared food recipes for a prosperous future Sweden. J Food Sci Tech 21: 45-49.

3. Christianson DD, Gardner HW, Warner K, Boundy BK, Inglett GE (1974) Xanthan gum in protein-fortified starch bread. Food tech 28: 23-28.

4. Scanlon MG, Dexter JE, Biliaderis CG (1988) Particle size related physical properties of flour produced by smooth roll reduction of hard red spring wheat farina. Cereal Chemistry 65: 486-492.

5. Gray JA, BeMiller JN (2003) Bread staling: Molecular basis and control. Compr Rev Food Sci Food Saf 2: 1-21.
6. Rodge AB, Ghatge PU, Wankhede DB, Kokate RK (2006) Isolation, purification \& rheological study of guar genotypes RGC-1031 and RGC-1038. J Arid Legumes 3: 41-43.

7. Kieffer R, Wieser H, Henderson MH, Graveland H (1998) Correlations of the breadmaking performance of wheat flour with rheological measurements on a micro-scale. J Cereal Sci 27: 53-60

8. AOAC (2005) Official Methods of Analysis of the AOAC International. (18 ${ }^{\text {th }}$ edn) Association of Official Analytical Chemists, Gaithersburg, MD.

9. AOCC (2000) Official Methods of Analysis of AACC international, American association of cereal chemists Washington D C.

10. Rodge AB, Ghatge PU (2008) Influence of temperature on rheological behaviour of guar (Cyanopsis tetragonoloba L.) gum extracted from various genotypes. J Arid Legumes (in press).

11. Ognean CF, Darie N, Ognean M (2006) Hypocaloric and Hypoglucidic Food On dough rheology and bread quality. Food Hydrocolloids 15: 75-81.

12. Sim SY LH Cheng, Noor Aziah AA (2009) Effects of selected food gums on wheat flour or dough properties. As. J Food Ag Ind 2: 937-947.

13. Collar C, Andreu P, Martınez JC, Armer E (1999) Optimization of hydrocolloid addition to improve wheat bread dough functionality: A response surface methodology study. Food Hydrocolloids 13: 467-475.

14. Whistler R, Bemiller J (1959) “Industrial gums”. Academics press, Newyork.

15. Tavakolipour H, Kalbasi-Ashtari A (2007) Influence of gums on dough properties and flat bread quality of two persian wheat varieties. J Food Process Eng 30: 74-87.

16. Trierum SL (2004) Whey and whey products in bakery applications. In Proceedings of the Whey Products Conference, Chicago, Illinois,132-135.

17. . Guarda A, Rossel CM, Benedito C, Galotto MJ (2004) Different hydrocolloids as bread improvers and antistaling agents. Food Hydrocol 18: 241-247.

18. Miyazawa T (2006) Hydrocolloid structure, which allow more water interactions through hydrogen bonding. Carbohydr Res 341: 870-877.

19. Rosell CM, Rojas JA, Benedito C (2001) Influence of hydrocolloids on dough rheology and bread quality. Food Hydrocol 15: 75-81. 